\title{
i

\section{An Exploratory Qualitative Study on Mobile Leisure (M-Leisure): A Case of Mobile Phone Users in Turkey ${ }^{1}$}

\section{Mobil boş zaman (m-leisure) üzerine keşifsel bir nitel araştırma: Türkiye'deki cep telefonu kullanıcıları örneği}

\author{
Sabri KAYA ${ }^{2}$, sabrikaya@kku.edu.tr \\ Metin ARGAN ${ }^{3}$, margan@anadolu.edu.tr
}

Geliş Tarihi/Received: 22.04.2015; Kabul Tarihi/Accepted: 19.08.2015

doi: 10.5505/iuyd.2015.47955

Anywhere in the world, billions of mobile phone users are chatting, messaging, spending their times, socializing with other users, and entertaining themselves. In Turkey, as in many other countries around the world, mobile phone has grown incredibly popular and become an object of collective attachment. From the leisure or recreation perspective, many mobile phone users are mostly engaging in spending time by smart phones. Mobile leisure (m-leisure) practice has gained attention as a phenomenon that can develop new application. The purpose of this study is to explore meaning of mobile phones within leisure context among Turkish college students. In-depth interview as qualitative research method was selected to collect and analyze data. Purposive sampling method was applied to individuals using mobile phone. In total, 25 students participated in this study, consisting of 13 men and 12 women. The results of this study revealed six themes titled as boredom and escape, engagement, socialization, entertainment, dependence and explore new experiences. The results highlight that both boredom and escape, and engagement were dominant dimensions for mobile users in leisure context. This research has also indicated that the use of mobile phones in leisure context mainly based on dependence and entertainment as well.

Keywords: Mobil phone use, Mobile leisure, College student

Jel Codes: L83, L82, I00.
Dünyanın her yerinde milyarlarca cep telefonu kullanicısı, diğer kullanıcılarla konuşmakta, mesajlaşmakta, vakit geçirmekte, sosyalleşmekte ve kendilerini eğlendirmektedir. Dünyadaki birçok ülkede olduğu gibi Türkiye'de de cep telefonu, oldukça popüler bir hal almış ve kolektif bağhllık nesnesi olmuştur. Boş zaman ya da rekreasyon açısından, cep telefonu kullanıcıları, çoğunlukla akıllı telefon ile meşgul olarak vakitlerini geçirmektedirler. Mobil boş zaman (m-leisure) uygulamast, yeni uygulamalarn geliştirilmesine yardımcr olabilecek bir olgu olarak önem kazanmıştır. Bu çalışmanın amacı, Türkiye'deki üniversite öğrencileri arasında, boş zaman (leisure) bağlamı kapsamında cep telefonlarının anlamını araştırmaktır. Verilerin toplanması ve analiz edilmesi için, nitel araştırma metodu olarak, derinlemesine görüşme seçilmiştir. Amaçlı örnekleme metodu, cep telefonu kullanan bireylere uygulanmıştır. Bu çalışmaya, 13'ü erkek ve 12'si kadın olmak üzere toplam 25 öğrenci katılmıştır. Çalışmanın sonucunda, can sıkıntısı ve kaçma, meşguliyet, sosyalleşme, eğlence, bağımlilık ve yeni deneyimler keşfetme başlığı altında altı tema ortaya çıkmıştır. Sonuçlar, hem can sıkıntısı ve kaçış hem de meşguliyet kavramlarının boş zaman bağlamı içerisinde cep telefonu kullanıcılar için daha baskın boyutlar olduğunu vurgulamaktadır. Bu araştırma ayrıca boş zaman açısından cep telefonu kullanımının temel olarak bağgmlılık ve eğlence boyutlarına da dayal olduğunu göstermiştir.

Anahtar Kelimeler: Cep telefonu kullanımı, Mobil boş zaman, Üniversite öğrencisi

Jel Kodlarn: L83, L82, I00.

\footnotetext{
${ }^{1}$ This study was submitted as an oral presentation at 37th Annual Southeastern Recreation Research Conference, March 22nd 24th 2015, Asheville, NC, USA.

2 Yard. Doç. Dr., Kırıkkale Üniversitesi, Spor Bilimleri Fakültesi (Yazışılan yazar)

${ }^{3}$ Prof. Dr., Anadolu Üniversitesi, Spor Bilimleri Fakültesi
} 


\section{INTRODUCTION}

Mobile or cell phones use dramatically changed our lives and relationships with people at the turn of the 21st century. Moreover, mobile phone can be considered as one of the most indispensable tools and it is also widely used as a means of leisure. Because of mobile phone allow us to interact with others from around the world- or a few kilometers away- from where we work or live, giving rise to the telecommunicating phenomenon and allowing us to stay in touch with friends and families in the new virtual environment. All over the world as well as in Turkey, mobile phones are becoming increasingly integrated into everyday life and changed people's lives and increasingly one of the most popular communication devices in less than a decade (Ling, 2000, 2004; Chen and Katz, 2009; Lepp et al., 2014). Mobile phones affect our daily lives and interactions of human relations in many ways directly and indirectly (Chen and Katz, 2009). Hasan and Nasir (2008) underlines that mobile phones today come out of the means of communication and offers features and services that give meaning to people's lives and facilitate moments of life. These features and services include multimedia messaging (MMS), text messaging (SMS), photo display and recording, video playback and recording, gaming, music listening, calendaring, etc (Hasan and Nasir, 2008). The mobile phone, in particular, has become a major attribute to the human existence and indeed, those who do not own a cell phone can find themselves relegated to an uncomfortable, almost inexcusable, minority (Powell, 2012). In fact, mobile devices especially cell phones, in its present-day digital version (GSM) sets out its history approximately in 1994 all over the world. Introduced in 1994 when Turkey was experiencing one of the worst economic crises in its history, the nation now 67,9 million (out of a 76 million population) mobile users and the largest second-hand market for mobile phone in the world and younger generations tend to appreciate them more and be more dependent on them (ICTA, 2014).

Many studies in recent years about mobile phone use, it is observed that mainly college students that the most common age group of mobile phone users (Ling, 2000, 2004; Hashimoto, 2002; Harper, 2003; Ellwood-Clayton, 2003; Karaaslan and Budak, 2012; Bae, 2001; Wilska, 2003; Caronia and Caron, 2004). The current study focuses on the individuals who were born between 1987 and 1994. Those aged between 18 and 24 years represent the college student population in Turkey. Lepp et al. (2015) stated that "cell phones are an integral part of college life and culture. Even a casual observation of today's college students will reveal cell phones being used, both overtly and covertly, in every possible campus setting, including the classroom."

Mobile phones are known to be very popular among university students, increasing their social inclusion and connectedness as well as providing a sense of security as they can contact others in times of distress or emergency (Balakrishnanand and Raj, 2012:263-272). As in many countries throughout the world, for young people in Turkey, the mobile phone has become a natural, fixed, stable part of daily life, life management and maintenance of social relationships. During the last few years, a general mobile literacy has developed among university students: the young consider mastering of the technological and communicative skills of mobile phone as something that has come to be required of citizens in the information society. The phenomenon can be viewed in connection with a larger norm of technology mastering. The attitude to the device itself has changed: the status symbol of the early years has been transformed into a tool for organizing everyday life, a standard 
accessory of all citizens and an expression of personal style and way of life. Such mobile ways of life and multi-locality are related not only to social or occupational obligations but also to leisure and free time (Gustafson, 2006; Rolshoven, 2007; McIntyre, 2009). There has been scarce attention paid to the determining factors influencing the usage of mobile phone recreation by the college students in Turkey. In this context, the main purpose of our study is to explore meaning of mobile phones within leisure context amongst Turkish college students.

\section{LITERATURE REVIEW}

Many studies have shown that using mobile phone is most popular devices worldwide, and that it was adopted more quickly and passionately by marginalized individuals, groups and countries (Schwarz, 1996; Katz and Aakhus, 2002; Agar, 2003). Selian (2004) stated that "the youth market today is an extremely technology-savvy one, a segment of society that has been active in transforming the application and use of digital technologies in unprecedented ways". This market segment here defined as the range of teenagers and young adults between the ages of 12 - 29 is more comfortable with using the Internet, building websites, communicating via mobile phones and playing with digital gadgetry than any previous generation. As seen in studies conducted in recent years, the use of mobile phones with different causes of young college students has increased extensively (Smith, 2005; Gustafson, 2006; Rolshoven, 2007; McIntyre, 2009; Powell, 2012; Balakrishnan\& Raj, 2012; White and Mills, 2012; Lepp, 2014; Lepp et al., 2015).

Recently, mobile devices become not only communication tools but also a leisure or recreational symbol. Besides, today's cell phones increase opportunities for activities traditionally defined as sedentary behaviors (e.g., surfing the internet, playing video games). Billions of cell phone users are chatting, messaging, spending their times in all over the world, socializing with other users, and entertaining themselves. From the leisure or recreation perspective, many mobile phone users are mostly engaging in spending time by smart phones. College students are more likely to use their cell phones for leisure than for school or work (Powell, 2012; Balakrishnan\& Raj, 2012; White and Mills, 2012; Dlodlo and Mahlangu, 2013; Lepp, 2014; Lepp et al., 2015). In this sense, mobile leisure (m-leisure) practice has gained attention as a phenomenon that can develop new application.

Dlodlo and Mahlangu (2013:874) stated that "encapsulates individuals using innovative tools such as mobile phones, smart phones, tablets and PDAs (personal digital assistants) as a platform to participate in recreational activities and hobbies". Much of the research (Lepp, 2014; Hsu, 2012; Lepp et al., 2013; Lepp et al., 2015) that has studied the use of mobile phones in leisure activities indicates a wide range of applications because these researches reveal experiential services for time spending. Pedersen (2005) indicates that research on mobile services in the leisure context has either focused directly on the functional use of mobile services and everyday contexts or on how the boundary between the work and leisure contexts is blurred by the use of such services. Lepp (2014) points out that mobile phone is likely to play multiple roles in leisure. Leisure studies reveal emerging areas of research for understanding the relationship between mobile phones and leisure (Lepp, 2014). These areas are maintaining relationships, perception and participation to risky activities, dependence, and demographic characteristics. Additionally, quality related to mobile service is such 
important for broadening users' leisure activities (Hsu, 2012). Many recent researches (Hsu, 2012; Lepp, 2013; Lepp et al., 2014; Lepp et al., 2015) show that many college students perceive the cell phone primarily as a leisure device, and most commonly use cell phones for social networking, surfing the Internet, watching videos, and playing games. Lepp (2014a) in his article exploring the relationship between cell phone use and leisure: an empirical analysis and implications for management stated that "mobile phone use is associated with an array of behaviors and behavioral outcomes, there is a need to better understand the potentially multi-faceted relationship between mobile phone use and leisure. Because the cell phone is so pervasive in modern life, an improved understanding of this relationship could have important implications for leisure service providers" (p.381).

From the perspective of college students, the modern cellular telephone (i.e. smart phone, mobile phone, and henceforth cell phone) is designed primarily for entertainment purposes (Lepp et al., 2015). In addition, Emanuel (2013) stated that a growing number of students fill the time between classes texting and talking on their cell phone or they are using their phone to listen to music, play a game, check their bank balance, or to use any number of other applications and features their phone provides. Studying cell phone use among college students is particularly important because they tend to be among the first to try new technology, they are the group most likely to innovate new ways of using existing technology, and they are most vocal about what they need and/or want to see changed technologically.

Research by Lepp et al. (2013) reported that college students use their cell phone primarily for leisure rather than for school or work. Because leisure is important for health and wellbeing and plays a critical role in promoting and maintaining mental and physical health (Mennel, 2007:114). According to Lepp's (2014) study "there is a complex and largely unexplored relationship between college students' cell phone use and leisure behavior".

The purpose of the present study was to explore the relationship between mobile phone use, meaning of mobile phones and perceptions of leisure among young adults attending college in Turkey. As a present study, this should be seen as one of the first steps in a much more extensive process devoted to understanding, and when necessary managing, leisure time mobile phone use. Therefore, mobile phone use has been associated with physical health, mental and social the relationship between cell phone use and leisure should be better understood. Consequently, the mobile phone amongst other ubiquitous devices has also become a convenient platform for the development of nontraditional recreational activities among the millennial generation (Wilska, 2003:441).

\section{METHOD}

Qualitative research methodology was applied to collect and analyze data. Purposive sampling method was applied to select individuals using mobile phone. This sampling method reflects "information rich cases" (Patton, 1990, p.169). Thus, selections of participants were based on the person and their leisure experiences in mobile phones. The participants were chosen from students of three universities in Turkey: one private and two state universities in Central Anatolia Region. In total, 25 individuals participated in this study, consisting of 13 men and 12 women. As a qualitative research technique, in-depth interview 
was used as the data collection method. The ages of participants ranged from 18 to 28 , with a mean of $22.1(\mathrm{SD}=2.6)$. The interviews were semi-structured and a short list of open-ended questions. As suggested by Rubin and Rubin (2005), follow-up questions were used in order to reach a deeper level of understanding of the responses given. The interviewers asked the university students about their daily use of mobile phones, about associated and leisure or recreational using practices. The interviews were audio recorded, transcribed verbatim. To ensure validity and reliability of data, multi investigators reviewed the data independently, and came to agreement upon both the coding categories.

Table 1. Interview Questions

Questions
1. What is the role of your mobile phone in your life?
2. What do you do in your free time on your mobile phone?
3. What experiences do you have in your daily life with your mobile phone?
4. What do you think about entertainment applications by mobile phones?
5. Could you share your experience on time spending by mobile phone?
6. What do you think about the applications of "Smart Phone" in your life?
7. What is the relationship between mobile phone and leisure time?
8. Imagine that you don't have a mobile phone. How do you describe this
situation?

\section{FINDINGS AND RESULT}

In this qualitative study carried out with 25 participants in order to study the importance of using mobile phone perceptions of leisure and perceptions of the cell phone's role in facilitating leisure, 6 main themes emerged as a result of the data collection through in-depth interview. These themes have been named as socialization, boredom and escape, engagement, entertainment, dependence and explore new experiences.

\section{Socialization}

Mobile phones have increased the socializing skills of people and youngsters especially have been using these phones to expand their external social network. (Ling, 2004). The results from the European Union's e-living project indicate that teenagers from Norway, the UK, Germany, Italy, Bulgaria and Israel use their mobile phones to arrange an array of social activities with friends (Ling et al., 2003:359 - 373). According to the findings obtained from the study, it has appeared that using cell phone is one of the unique means of socialization. Interviewers has associated smart cell phone with such elements as chat, conversation, text message, friendship and sharing. Interview data from our study provided several explanations by mobile phone college student users' states view as follows:

"I view my cell phones as my best friend, a friend in pocket, such a little gadget and you carry around in your pocket and you can chat, you can click pictures, you can send pictures and text message, you can store everything in cell phone's memory. It's like everything. It's really important.... can say that I love my cell phone. ....the first thing in the morning is my cell phone and the last thing before I go to 
bed is my cell phone, cell phone, cell phone, cell phone." (Esra, female, 20 years, faculty of tourism).

According Dimmick, Sikand and Patterson (1994), mobile phones integrate interpersonal relations into the mass communication. So this contributes to socialization in a positive way. The news spread in mass are transferred to known people through special communication channels, thus contributing positively to the socialization process.

\section{Boredom and Escape}

Boredom and escape can be considered as one of many motivational elements in leisure and recreation context. In this context, while preferring leisure time activities, boredom and escape motives are important factors. The primary reasons for young generation to use mobile phone are boredom and escaping daily life routines. As stated earlier, for the participation in a number of indoor and outdoor activities escape is a basic means of motivation. That is the similar case regarding the smart phones that have become today's most important device. The individual who have become alone in the crowd turn onto the mobile devices as a means of escaping this situation. The relationship that cannot be established with the large mass of people is replaced with the relations with mobile phones. With this aspect, the mobile phone is seen to be widely used for escaping from the problems and to overcome boredom. (Lopez-Fernandez et al., 2014) Escape from the stress factors caused by the life also exists in mobile leisure as in traditional leisure activities. So related to this case, one of the people, (Ali, male, 24 years, faculty of business administration) interviewed with stated as follows:

"Whenever I get bored, I find myself spending time with my phone. Now it has become like a reflex. I am busy with its functions randomly or playing games on it. Indeed, I cannot concentrate on those. But I don't know; maybe I escape from myself, from brain twisters or maybe from life."

\section{Engagement}

One of the most important opportunities offered for users by smart phones is to make them engage with those phones. With the help of many applications and mobile internet connection, these cell phones cause people to be in continuous involvement. The instant messages (eg. Whats App), e-mails and social media applications sent to the users keep this engagement endlessly and increase it. The quotation below paying attention to the Engagement issue can summarize this situation:

"I do not know what I would do without mobile phone or Facebook. I sometimes ask myself this question: What was I doing before Facebook and mobile phone was created? I can forget my purse or a book related to the exams, but never can I forget my phone. My phone has become like a part of my body. I mean it is indispensable." (Leman, female, 24 years, faculty of sport sciences).

This person has emphasized the time perception as a means of motivation that is supportive for Engagement issue. Time perception has increased mobile engagement phenomenon in supporting way. Mobil users apply to the mobile engagement when they want to use or spend time in a fast way. In other words, as a reflection of post-modern consumption, there is also a desire to waste time quickly like every object. Related to this situation, following expressions were stated: 
"Sometimes I do not understand how fast the time passes. Earlier, while I was traveling to my hometown by bus, the road seemed to be never-ending. But many times I do not understand how the time passes with the help of mobile phone. I listen to the music, surf on Facebook, send messages via Whats App and watch funny videos on YouTube to spend time. That is, I can find something to be busy with." (Hilal, female, 24 years, Civil Engineering).

\section{Entertainment}

Using mobile phones has produced an approach focusing on pleasure and symbolizes the hedonic dimension of the phone (Davis, Bagozzi and Warshhaw, 1992). Both the pleasure that is given by using the phone itself and the pleasure taken by using the applications are considered within this scope. Entertainment is amusement. Its purpose is to create a relaxing, enjoyable environment in which to temporarily escape the stresses of daily life. It has taken countless forms over the centuries, ranging from recreational amusement such as jogging or painting to passive entertainment like watching television or listening to music, playing games by using cell phone. Entertainment can also take the form of everyday activities, for example, gardening or cooking. In fact, the list of activities that could be considered entertainment is virtually endless and differs from person to person.

"Mobile phone is like a lifeline to me. Lifeline because see, I need to be in constant touch with my parents and outside world....in mobile phones I can access news, in any corner of the world, I can reach with mobile phones, with just a palm in my hand. So mobile phone is like a lifeline to me, it gives me all the information related to education, business, sports, entertainment and leisure" - Hakan, male, 21 years, Faculty of Law)

\section{Dependence}

As in most technologies today, the dependence on the mobile phones is at highest rate. In fact, more than the dependence on the phone itself, the one on its easiness, access and services have increased. For example, it is reported, according to a study, that the young get on Facebook at an average of 10 to 30 minutes. Similarly, the rate of dependence on messaging between friends is also high. Regarding dependence, one participant of the study (Ahmet, male, 24 years old, and faculty of communication science) stated as follows:

"I keep the phone by me while sleeping at night. When I wake up sometimes at night, I cannot help checking my messages or social media accounts. Many times I may become sleepless for this reason. I can sleep if I do not check them but I cannot help."

Dependence both on the phone and on the peers is regarded as problematic phone use. (Foerster et al., 2015). The phenomenon of dependence on Mobil phone refers to over use of it. As stated by the participant above, the use of the phone that may damage to one's health is the result of this dependence. The over use of the phones at free times can be considered within this context.

\section{Explore New Experience}

The last theme regarding the use of Smart phone as leisure is "explore new experiences". Mleisure which is characterized as the entrance door of the world reveals entertainment, having great time, learning and discovery of new fields focusing on aesthetics. The applications that have become popular or common especially among friends are getting 
popular among young generation by means of word of mouth communication. In addition, the mobile applications or updates in smart phones can also be evaluated within this scope. Opinions, Videos, social facts and things that are shared by social media but not known by the participant characterize the new experiences, too. One of the participants taking part in this survey regarding this issue stated as follows (Mustafa, male, 24 years, faculty of sport sciences):

"I have been discovering new things thanks to mobile phone. Even I learn the things I don't know, and understand how much I do not know. Namely, it teaches new things related to my lessons. Moreover, my friends upload videos. Most of them are funny and we watch them and have fun. We have recently watched the abilities of a gymnast and got amazed. We supposed that we had known gymnasium."

\section{DISCUSSION AND CONCLUSION}

The results of this study revealed six themes titled as boredom and escape, engagement, socialization, entertainment, dependence and explore new experiences. Socialization is a dominant phenomenon in the use of mobile phones just as in all recreational and leisure time activities. Youngsters gathered for any reason often share their mobile phone applications in any occasion and environment. This can be stated to occur as a reflection of socialization. Boredom and escape can be accounted as the basic factors for the leisure or recreational use of mobile phones quite similar to the traditional recreational activities. Considering that the technology acceptance level of the $Z$ generation is very high, it can be said that technological mobile devices such as mobile phones, tablet computers are more often used as tools to overcome boredom. Engagement can be characterized as a factor bringing forth the tool to overcome boredom and spend time. Especially the quick consumption pace of the younger generation and their contentment levels lasting for shorter periods of time as a reflection of the postmodern consumption renders the mobile devices rather more effective. Mobile devices used by the university youth as a means of pastime activity can be considered, in this context, as another reflection of spare time. The third factor to point out as a tool to spend leisure time is entertainment which can currently be expressed as the most important fun wave. In rendering an experience unique or worth remembering, entertainment has a determinative role. Another important factor, dependence, symbolizes addiction to technology on one hand and to the devices on the other.

In our day where a life, a period of time or even a moment without mobile phones is not possible or is very difficult, the mobile devices have become almost inseparable parts of humans. This can be evaluated as a signifier of addiction both to the mobile device itself and the mobile applications (such as Facebook, Twitter etc.) experienced via the mobile device. As a result, discovering new experiences can also be stated as the basic determinant of mobile leisure. Nowadays, experience has become the main factor where majority of the time spent awake is shared via the mobile devices. The sharing of the experience, in context of making it everlasting, also depends on mobile devices. When most emphasis on the subject made among participant in this study, it can be expressed that the results highlight that both boredom and escape, entertainment and engagement were dominant dimensions for mobile users in leisure context. This research has also indicated that the use of mobile phones in leisure context mainly based on dependence and entertainment. 
The results of this study predict that the majority of college students involved in this study agreed to some extent that mobile phones help them relax, make leisure more enjoyable, increase personal freedom, are intrinsically rewarding, make it easier to experience leisure, increase opportunities for leisure, relieve boredom, make solitude more enjoyable, make leisure more meaningful. This study is of great importance, in terms of the fact that within the scope of different culture and lifestyle, the students at universities in Turkey regard mobile phones as a means of fun, socialization, relaxation, relief from boredom, discovering new things and using free time apart from a means of communication. It has been observed that the participants structure their interpretation regarding mobile phones and using leisure time over the feature of the cell phone as a means of communication. Mobile phones are increasingly one of the most popular information access devices in Turkey too. They have an extensive and continuing effect on how people communicate among themselves and how people conduct their day to day lives. This study is the first of its kind in Turkey and therefore opens up a pathway for others to extend and study further research into the subject.

As a conclusion, this research helps the practitioners to better understand opportunities of mobile services in leisure industry. As we know that the modern cell phone is designed to entertain. Yet, the potential intersection of cell phone use and leisure has not been well explored. Therefore, there is a need for research in this area. As we know that the mobile phone becomes increasingly embedded in our lives, we should strive to understand how the mobile devices influence the leisure of users as well.

\section{LIMITATION AND FUTURE STUDIES}

Like all scientific and particularly qualitative researches, this study has also limitations. This study having the characteristics of guiding the next researches is concerned with the use of mobile phone by associating it with individuals' using leisure time. The fact that this qualitative research is generalized for throughout Turkey is impossible due to its qualitative feature. From this respect, the study has some certain limitations that must be emphasized. In terms of the methodological technique adopted, this study is a definitive one and the issue must be dealt with in the next studies by using the methods of qualitative and quantitative researches together. The participants of the in-depth interview are composed of students studying at two state and one private universities selected. Therefore, in the study, only the fact that a certain age and social group associate mobile phone use in their daily lives with the phenomenon of using free time is evaluated. In the next studies, to focus on a research group representing the whole society is necessary in order to determine the interaction between the use of mobile phone and the use of free time. Although the mobile phone is characterized as a global product, the use of it as the content is affected by the culture. For this reason, the researches that will encompass different cultures and countries could provide more generalizable results. Suggested future research could be scale the study to a larger more representative sampling across the country. The authors believe that the study will contribute valuable learning's about the field of mobile communication to the broader academic knowledge base. This research may serve as useful input and have practical benefits to marketers, mobile phone developers, researchers (information science, social communication, etc.), universities and media futurists and parents in Turkey. 


\section{Acknowledgment}

This study was submitted as an oral presentation at 37th Annual Southeastern Recreation

Research Conference, March 22nd - 24th 2015, Asheville, NC, USA.

\section{REFERENCES}

Agar, J. (2003). Constant touch; a brief history of the mobile phone, Cambridge; Icon Books, pp. 15-35

Bae, J. H. (2001). Generation effect on gratification obtained from mobile phone use and perception as interpersonal communication medium. Korean Journalism and communication Studies, 45: 160 -188.

Balakrishnan, V. \& Raj, R. G. (2012). Exploring the relationship between urbanized Malaysian youth and their mobile phones: A quantitative approach. Telematics and Informatics, 29 (3): 263-272.

Caronia, L. \& Caron, A. H. (2004). Constructing a specific culture: Young people's use of the mobile phone as a social performance. Convergence, 10 (2): 28 - 61.

Chen Y.F. (2007). The mobile phone and socialization: The consequences of mobile phone use in transitions from family to school life of U.S. College students. Unpublished Dissertation. Graduate School - New Brunswick, Rutgers, The State University of New Jersey.

Chen Y.F. \& Katz J. (2009), Extending family to school life: College students use of the mobile phone, Human-Computer Studies, 67 (2): 179-191.

Çelik, B. (2011). "Cellular telephony in Turkey: A technology of self-produced modernity", European Journal of Cultural Studies, 14 (2): 147-161

Davis, F.D., Bagozzi, R.P. \&Warshhaw, P.R. (1992). Extrinsic and intrinsic motivation to use computers in the workplace. Journal of Applied Psychology, 22 (14): 1111-1132.

Dimmick, J., Sikand, J. \& Patterson, S.J. (1994). The gratifications of the household telephone: Sociability, instrumentality, and reassurance. Communication Research, 21: 643-663.

Dlodlo, N. \&Mahlangu, H.B. (2013). Usage of mobile-devices for recreation among the millennial generation. African Journal for Physical, Health Education, Recreation and Dance, 19 (4:2): 874-890.

Ellwood-Clayton, B. (2003). Virtual Strangers: Young Love and texting in the Filipino archipelago of cyberspace. In: Mobile Democracy: essays on Society, Self and Politics. Nyiri, K. (eds), Vienna: PassagenVerlag: pp. 35 - 45.

Emanuel, R.C. (2013). The American College Student Cell Phone Survey. College Student Journal, 47 (1): 75-81.

Foerster, M., Roser. K., Schoeni, A., \& Röösli, M. (2015). Problematic mobile phone use in adolescents: derivation of a short scale MPPUS-10. International Journal of Public Health, 60: 277-286. 
Gustafson, P. (2006). Place attachment and mobility. In McIntyre N, Williams D \& McHugh $\mathrm{K}$ (eds). Multiple dwelling and tourism: negotiating place, home and identity, 17-31. Cabi, Wallingford.

Harper, R. (2001). 'The Mobile Interface: Old Technologies and New Arguments', in Brown, B., Green, N. and Harper, R. (eds) Wireless World: Social and Interactional Aspects of the Mobile Age, Springer, London, pp.207-224.

Hashimoto, Y. (2002). The Spread of Cellular Phones and Their Influence on young people in Japan. In: The Social and Cultural Impact /Meaning of Mobile Communication, Kim, S. D. (eds), Chunchon: Korea: School of Communication, HAlym University, pp.101-112.

Hassan, H., \& Nasir, M.H.N. (2008). The use of Mobile Phones by Older Adults: A Malaysian Study. Sigaccess Newsletter, 92, 3.

Hsu, C. (2012). An Exploration on the Mobile Service for Leisure Marketing in Taiwan. Journal of International Management Studies, 7 (2): 177-183.

ICTA (2014). Quarterly Market Data Report. Turkish Information and Communication Technologies Authority, Ankara.

Karaaslan, I.A., \&Budak, L. (2012). Research on the use of mobile phone features by university students and its impact on their communication practices in everyday life. Journal of Yasar University. 26 (7): 4548 - 4571

Katz, J., Aakhus, M. (eds) (2002). Perpetual contact: Mobil communication, private talk, public performance, Cambridge; Cambridge University press, pp.43-66.

Lepp, A. (2014a). Exploring the relationship between cell phone use and leisure: an empirical analysis and implications for management, Managing Leisure, 196 (6): 381-389.

Lepp, A., Barkley, J. E., Sanders, G. J., Rebold, M., \& Gates, P. (2013). The relationship between cell phone use, physical and sedentary activity, and cardio respiratory fitness in a sample of U.S. college students. International Journal of Behavioral Nutrition and Physical Activity, 10:79, 1 -9.

Lepp, A. (2014b). The intersection of cell phone use and leisure: A call for research. Journal of Leisure Research, 46 (2): 218 - 225.

Lepp, A., Li, J., Barkley, J.E., \&Esfahani, S.S. (2015). Exploring the relationships between college students' cell phone use, personality and leisure. Computers in Human Behavior, 43: 210-219.

Ling, R. (2000). We will be reached: The use of mobile telephony among Norwegian youth. Journal of Information Technology and People, 13 (2): 102-120.

Ling, R. (2004). The mobile connection: The cell phone's impact on society. San Francisco, CA: Morgan Kaufmann Publishers.

Ling, R., Yttri, B., Anderson, B., \&DiDuca, D. (2003). Mobile communication and social capital in Europe. In K. Nyiri (Ed.), Mobile Democracy: Essays on Society, Self and Politics, pp. 359 - 373. Vienna: PassagenVerlag. 
Lopez-Fernandez, O., Honrubia-Serrano, L., Freixa-Blanxart, M., \& Gibson, W. (2014). Prevalence of problematic mobile phone use in British adolescents. Cyber Psychology, Behavior \& Social Networking, 17 (2): 91-98.

Mannell, R. C. (2007). Leisure, health and well-being. World Leisure Journal, 49 (3): 114-128.

McIntyre, N. (2009). Re-thinking amenity migration: integrating mobility, lifestyle and socialecological systems. Die Erde, 140 (3): 229-250.

Meyers, N. P., \& Barnes, M.C. (2011). Mobile Phones: Technology, Networks, and User Issues. Nova Science Publishers, Inc., New York.

Patton, M.Q. (1990). Qualitative Evaluation and Research Methods (2nd Ed.). Newbury Park, CA: Sage.

Pedersen, P.E (2005). Adoption of mobile internet services: an exploratory study of mobile commerce early adopters, Journal of Organizational Computing and Electronic Commerce, 15 (3): 203-222.

Powell, C. (2012). Me and my cell phone and other essays on technology in everyday life. Langaa Research \& Publishing. Mankon, Bamenda.

Rolshoven, J. (2007). The temptations of the provisional: multilocality as a way of life. Ethnologia Europaea, 37 (1-2): 17-25.

Rubin, H.J. \& Rubin, I.S. (2005). Preparing follow-up questions. In H.J.Rubin and I.S. Rubin (Eds.). Qualitative Interviewing: The Art of Hearing Data. (2nd Ed.), pp. 173-200. Sage, Thousand Oaks, CA.

Schwartz, R. (1996). Wireless communication in developing countries: Cellular and satellite system, Norwood, MA: Artech House Publisher, pp. 22-44.

Selian, A. (2004). Mobile phones and youth: A look at the US student market. Paper prepared for the International Telecommunication Union (ITU). Retrieved 17 March 2015 from http://www.itu.int/osg/spu/ni/futuremobile/Youth.pdf

Smith, I. (2005). Social-mobile applications. IEEE Computer, 38 (4): 84-85.

White, J., \& Mills, D.J. (2012). Examining attitudes towards and usage of smart phone technology among Japanese university students studying EFL. CALL-EJ, 15(2): 1-15.

Wilska, T.A. (2003). Mobile phone use as part of young people's consumption styles. Journal of Consumer Policy, 26(4): 441-463. 